\title{
Prawna ocena wyłączenia obowiązywania I progu ostrożnościowego w ustawie o finansach publicznych
}

\section{Legal Assessment of the Legal Force Exclusion of the $1^{\text {st }}$ Prudential Procedure in the Act on Public Finance}

Streszczenie. Nowelizacją ustawy o finansach publicznych z dnia 26 lipca 2013 r. polski ustawodawca dokonał czasowego, tj. do końca 2013 r., zawieszenia stosowania przepisów regulujących tzw. I procedurę ostrożnościową. Procedura ta ma istotne znaczenie dla ograniczania wzrostu deficytu budżetowego, co w konsekwencji ma również służyć ograniczeniu wzrostu długu publicznego. W przypadku tak kluczowych dla finansów publicznych przepisów, wszelkie ich zmiany powinny być przeprowadzone, z jednej strony w sytuacjach rzeczywiście uzasadnionych i wyjątkowych, z drugiej zaś - ze szczególnym zachowaniem tzw. zasad przyzwoitej legislacji. W tych aspektach powoływana nowelizacja budzi szereg zastrzeżeń, już chociażby błyskawiczne tempo prac parlamentarnych budzi wątpliwości co do rzetelności procesu legislacyjnego. W związku z tym w niniejszym artykule autor stara się dokonać prawnej oceny nowelizacji ustawy o finansach publicznych z dnia 26 lipca 2013 r., zarówno z formalno-prawnego punktu 
widzenia, jak i mając na uwadze znaczenie przepisów regulujących procedurę ostrożnościową dla finansów publicznych.

Słowa kluczowe: równowaga budżetowa; deficyt budżetowy; dług publiczny; procedura ostrożnościowa (próg ostrożnościowy); legislacja finansowa.

\begin{abstract}
By the amendment of the Act on Public Finance of 26 July 2013, Polish legislature made a temporary suspension - till the end of 2013 - of the application of the provisions governing the $I^{\text {st }}$ prudential procedure. This procedure has a crucial meaning for reducing the growth of budget deficit and in consequence - reducing public debt growth. In case of such crucial provisions for public finance, any amendments should be carried out in situations really justified and exceptional as well as with careful respecting of principles of proper legislation. In these aspects mentioned amendment rises a number of objections. For example, rapid pace of parliamentary works causes doubts about correctness of the legislative process. Therefore, in this article the author tries to make a legal assessment of the amendment of the Act on Public Finance of 26 July 2013, both from the formal and legal point of view and taking into the consideration the importance of provisions governing the prudential procedure for whole sphere of Polish public finance.
\end{abstract}

Keywords: budget equilibrium, budget deficit, public debt, prudential procedure (prudential threshold), financial legislation.

\title{
1. Uwagi wprowadzające
}

Nowelizacją ustawy o finansach publicznych z dnia 26 lipca 2013 r. ${ }^{1}$ ustawodawca postanowił o czasowym zawieszeniu stosowania przepisów regulujących dwie istotne instytucje dotychczas funkcjonujące w systemie finansów państwa. Pierwsza z nich to określona w art. 86 ust. 1 pkt 1 ustawy o finansach publicznych ${ }^{2}$ tzw. I procedura ostrożnościowa, której celem była redukcja wzrostu wysokości deficytu budżetowego w przypadku, gdy państwowy dług publiczny w stosunku do produktu krajowego

1 Ustawa z dnia 26 lipca 2013 r. o zmianie ustawy o finansach publicznych (Dz.U., poz. 938).

2 Ustawa z dnia 27 sierpnia 2013 r. o finansach publicznych (tekst jedn. Dz.U. z 2013 r., poz. 885 ze zm.), dalej: u.f.p. 
brutto (PKB) przekroczy poziom 50\%, i jednocześnie nie przekroczy 55\%. Druga z kolei to tzw. tymczasowa reguła wydatkowa uregulowana w art. 112a i 112b, ograniczająca wzrost wydatków z budżetu państwa na zadania publiczne na dany rok ponad określony poziom, tj. nie więcej niż o prognozowany wskaźnik inflacji powiększony o jeden punkt procentowy.

Stosownie do ustawy nowelizującej zawieszenie mocy obowiązującej wskazanych przepisów dotyczyło tylko roku 2013, przy czym skutek omawianych zmian legislacyjnych ma miejsce również w roku 2014. Wynika to z faktu, iż mechanizmy ograniczające wzrost deficytu i wydatków budżetu państwa odnosiły się do procesu konstruowania projektu budżetu państwa na kolejny rok budżetowy. W efekcie minister finansów oraz Rada Ministrów, przygotowując projekt budżetu na rok 2014, nie były związane restrykcjami wynikającym z art. 86 ust. 1 pkt 1 i art. 112a u.f.p. Z kolei mając na uwadze kolejną zrealizowaną inicjatywę legislacyjną rządu w odniesieniu do ustawy o finansach publicznych, I procedura ostrożnościowa w ogóle została zniesiona, a tymczasowa reguła wydatkowa zastąpiła tzw. stabilizująca reguła wydatkowa ${ }^{3}$.

Powracając do samej ustawy nowelizującej, jest ona aktem bardzo krótkim, zawiera bowiem dwa artykuły. Pierwszy, w kolejnych ustępach wprowadził do ustawy o finansach publicznych art. 86a i 112e, zawieszające funkcjonowanie wspomnianych instytucji, drugi - to przepis określający wejście w życie nowelizacji. Nie oznacza to bynajmniej, że można ją uznać tylko za legislacyjno-techniczny zabieg ustawodawcy. Ze względu na kluczowe znaczenie obu instytucji ograniczających wzrost deficytu budżetowego i długu publicznego, wszelkie zmiany w tym zakresie powinny być przeprowadzone w sytuacjach rzeczywiście uzasadnionych i wyjątkowych oraz ze szczególnym zachowaniem tzw. zasad przyzwoitej legislacji. W tym kontekście analizowana nowelizacja budzi szereg zastrzeżeń. Już samo błyskawiczne tempo prac parlamentarnych wywołuje wątpliwości co do rzetelności procesu legislacyjnego. Projekt ustawy został wniesiony do Sejmu 17 lipca, a już 26 lipca został przedstawiony

3 Ustawa z dnia 8 listopada 2013 r. o zmianie ustawy o finansach publicznych oraz niektórych innych ustaw (Dz.U., poz. 1646). 
prezydentowi do podpisu, by ostatecznie wejść w życie 20 sierpnia 2013 r. ${ }^{4}$ Paradoksalnie więc prezydent dłużej analizował uchwaloną ustawę (podpisał ją 19 sierpnia), niż pracowały nad nią obie izby parlamentu.

W związku z powyższym w niniejszym artykule autor stara się dokonać prawnej oceny nowelizacji ustawy o finansach publicznych z dnia 26 lipca 2013 r. zarówno z formalno-prawnego punktu widzenia, jak również mając na uwadze znaczenie przepisów regulujących procedurę ostrożnościową dla finansów publicznych. Przy czym artykuł będzie koncentrował się głównie na zmianach dotyczących I procedury ostrożnościowej, zaś w mniejszym stopniu odniesie się do tymczasowej reguły wydatkowej.

\section{Znaczenie procedur ostrożnościowych i sanacyjnych w ograniczaniu państwowego długu publicznego}

I procedura ostrożnościowa należała do jednej z trzech procedur ostrożnościowych i sanacyjnych uregulowanych w art. 86 u.f.p. Wszystkie one stanowiły spójne instrumentarium kontrolno-nadzorcze, które miały na celu przeciwdziałanie sytuacji, w której państwowy dług publiczny w stosunku do PKB osiągnie lub przekroczy poziom 60\%, co w takim wypadku stanowiłoby złamanie art. 216 ust. 5 Konstytucji RP ${ }^{5}$. Przekroczenie kolejnych progów wyznaczonych stosunkiem państwowego długu publicznego do PKB, tj. 50\%, 55\% i 60\% (w przypadku ostatniej wartości już nawet jej osiągniecie) będzie skutkowało wszczęciem odpowiedniej procedury ${ }^{6}$ i podjęciem w jej ramach stosownych działań ograniczających

4 Zob. przebieg procesu legislacyjnego dotyczący projektu ustawy o zmianie ustawy o finansach publicznych (druk sejmowy $\mathrm{nr}$ 1575), http://sejm.gov.pl/Sejm7.nsf/ proces.xsp (dostęp: 25 listopada 2013 r.).

5 Konstytucja Rzeczypospolitej Polskiej z dnia 2 kwietnia 1997 r. (Dz.U. Nr 78, poz. 483 ze zm.).

6 Ustawodawca jednoznacznie nie wskazuje, które z procedur mają charakter ostrożnościowy, a które sanacyjny. Również w literaturze ekonomiczno-finansowej brak tak ścisłego rozgraniczenia. Natomiast w opinii autora pierwsza procedura jest ostrożnościowa, dwie następne - sanacyjne. Uzasadnienie dla tej tezy zob. M. Tyniewicki, 
wydatki publiczne, co w konsekwencji ma służyć zahamowaniu wzrostu oraz redukcji zadłużenia. W istocie rzeczy więc procedury te powinny przeciwdziałać naruszeniu powoływanej regulacji konstytucyjnej. Należy zauważyć, że im wyższy poziom wspomnianej relacji, tym podejmowane kroki naprawcze są bardziej restrykcyjne. Przykładowo w ramach I procedury ostrożnościowej, tj. gdy relacja długu do PKB przekroczyła 50\%, a nie osiągnęła 55\%, Rada Ministrów była zobowiązana w projekcie ustawy budżetowej na kolejny rok zachować relację deficytu budżetu państwa do jego dochodów na tym samym poziomie, na którym ta relacja kształtowała się w budżecie w roku bieżącym. Jeżeli jednak poziom długu przekroczy 55\%, a nie osiągnie 60\%, to następstwem takiej sytuacji będzie m.in. obowiązek przedstawienia przez Radę Ministrów na kolejny rok projektu ustawy budżetowej pozbawionego deficytu lub przyjęcia takiego poziomu różnicy dochodów i wydatków budżetu państwa, który gwarantuje, że relacja długu Skarbu Państwa do PKB przewidywana na koniec roku budżetowego, którego dotyczy projekt ustawy, będzie niższa od tej samej relacji za bieżący rok budżetowy.

Procedury ostrożnościowe i sanacyjne po raz pierwszy wprowadzono do polskiego systemu prawnego ustawą o finansach publicznych z 1998 r. ${ }^{7}$ W podobnym kształcie funkcjonowały również w ustawie z roku $2005^{8}$. W zasadzie ich treść była podobna (tak jak w ustawie obowiązującej), a różnice występowały jedynie w odniesieniu do podejmowanych działań ograniczających wydatki publiczne. Co więcej, rząd w projekcie obecnej ustawy o finansach publicznych planował wprowadzenie nawet czterech procedur ${ }^{9}$ (co należy ocenić jednoznacznie pozytywnie) z których pierwsza miałaby już zastosowanie w przypadku przekroczenia poziomu 47\%. Ostatecznie jednak na etapie prac sejmowych

Procedury ostrożnościowe i sanacyjne, [w:] E. Ruśkowski, J.M. Salachna (red.), Finanse publiczne. Komentarz praktyczny, Gdańsk 2013, s. 367-368.

7 Ustawa z dnia 26 listopada 1998 r. o finansach publicznych (tekst jedn. Dz.U. z 2003 r. Nr 15, poz. 148 ze zm.).

8 Ustawa z dnia 30 czerwca 2005 r. o finansach publicznych (Dz.U. Nr 249, poz. 2104 ze zm.).

$9 \quad$ Art. 81 projektu ustawy o finansach publicznych z dnia 20 października 2008 r. (druk sejmowy nr 1181). 
zrezygnowano z propozycji rządowej i poprzestano na poprzednio obowiązujących rozwiązaniach. ${ }^{10}$

Odpowiedź na pytanie o przyczynę ustanowienia procedur w 1998 r. nie powinna stanowić problemu w świetle art. 216 ust. 5 Konstytucji RP. Wynika z niego obowiązek zachowania państwowego długu publicznego poniżej 3/5 PKB, który należy uznać za niezwykle restrykcyjny, a jego złamanie jest możliwe tylko w wyjątkowych przypadkach, np. uzasadnionych wystąpieniem jednego ze stanów nadzwyczajnych (zob. rozdział XI Konstytucji RP). Poza nimi przekroczenie wyznaczonych konstytucyjnych granic zadłużenia należy uznać za postępowanie do tego stopnia naganne, że powinno być „(...) traktowane jako «delikt konstytucyjny» niezależnie od tego, czy konkretne osoby podlegają odpowiedzialności konstytucyjnej, czy nie.”"

Ustawa o finansach publicznych z 1998 r. dosyć szeroko potraktowała problematykę długu publicznego, co, jak podkreślano, było wyrazem dbałości o zdrowe finansowe publiczne, wzmacniało stabilność i przewidywalność polityki makroekonomicznej, a procedury ostrożnościowe i sanacyjne wychodziły naprzeciw wymogom art. 216 ust. 5 Konstytucji RP oraz fiskalnym kryteriom konwergencji ówczesnego Traktatu z Maastricht. ${ }^{12}$ Tak więc procedury ostrożnościowe i sanacyjne zaprojektowane zostały jako spójny zespół instrumentów prawnych realizujących konstytucyjną normę, której przedmiotem regulacji jest limitowanie rozmiarów długu publicznego, przy czym instrumenty te posiadają wieloaspektowy charakter. Z normy tej bowiem wynika obowiązek ciążący na odpowiednich organach w zakresie czuwania nad stanem zadłużenia, jego monitorowania i podejmowania z wyprzedzeniem działań ostrożnościowych i zapobiegawczych. ${ }^{13}$ Należy zgodzić się z T. Dębowską-Romanowską, że: „Procedury ostrożnościowe, sanacyjne i naprawcze są więc niejako «wpisane» w art. 216 ust. 5 Konstytucji RP. W artykuł ten «wpisany» jest

10 M. Tyniewicki, Procedury ostrożnościowe..., s. 364-365.

11 T. Dębowska-Romanowska, Prawo finansowe. Część konstytucyjna wraz z częściq ogólnq, C.H. Beck, Warszawa 2010, s. 119.

12 Uzasadnienie do projektu ustawy o finansach publicznych z dnia 14 maja $1998 \mathrm{r}$. (druk sejmowy nr 342), s. 8.

13 T. Dębowska-Romanowska, Prawo finansowe..., s. 120. 
także nakaz ustawowego zapewnienia dostatecznego instrumentarium prawnego dla organów monitorujących - tak, aby mogły one zapobiegać zagrożeniu, zamiast reagować na nie po fakcie”14. Trybunał Konstytucyjny wielokrotnie podkreślał, mając na uwadze postanowienia art. 216 ust. 5 oraz art. 220 ust. 1 Konstytucji RP, że dbałość o stan finansów państwa, w tym o zachowanie równowagi budżetowej, stanowią wartości (zasady) konstytucyjnie chronione ${ }^{15}$. Ich waga niejednokrotnie pozwala na uchylenie stosowania innych zasad konstytucyjnych, takich, jak ochrona praw nabytych $^{16}$ czy nakaz odpowiedniej vacatio legis ${ }^{17}$. Z drugiej jednak strony równowaga budżetowa i stabilność finansowa nie mają charakteru bezwzględnego, bowiem „Konstytucyjna wartość, jaką jest równowaga budżetowa, nie może służyć legitymizacji ograniczeń praw i wolności w sytuacji, w której zagrożenie dla równowagi budżetowej tkwi nie tyle w wykonywaniu tych praw i wolności przez jednostki, ile stanowi bezpośrednio następstwo - podejmowanych z naruszeniem tejże równowagi działań prawodawczych" ${ }^{\text {.18. }}$

W istocie rzeczy więc regulacje ustanawiające procedury ostrożnościowe i sanacyjne na poziomie ustawowym realizują konstytucyjne zasady ograniczania zadłużenia państwa oraz równowagi budżetowej.

\footnotetext{
Tamże, s. 120.

5 Wyrok Trybunału Konstytucyjnego z dnia 4 grudnia 2000 r., K 9/00, OTK ZU 2000, nr 8, poz. 294; wyrok Trybunału Konstytucyjnego z dnia 13 grudnia 2004 r., K 20/04, OTK ZU 2004, nr 11A, poz. 115; wyrok Trybunału Konstytucyjnego z dnia 4 maja 2004 r., K 40/02, OTK ZU 2004, nr 5A, poz. 38.

16 Wyrok Trybunału Konstytucyjnego z dnia 9 marca 2004 r., K 12/02, OTK ZU 2004, nr 3A, poz. 19 .

17 Wyrok Trybunału Konstytucyjnego z dnia 15 lipca 2013 r., K 7/12, OTK ZU 2013, nr 6A, poz. 76.

18 Wyrok Trybunału Konstytucyjnego z dnia 6 marca 2013 r., Kp 1/12, OTK ZU 2013, nr 3A, poz. 25; zob. również wyrok Trybunału Konstytucyjnego z dnia 17 grudnia 1997 r., K. 22/96, OTK ZU 1997, nr 5-6, poz. 71.
} 


\section{Procedura nowelizacji ustawy o finansach publicznych zawieszającej obowiązywanie I procedury ostrożnościowej a zasady przyzwoitej legislacji}

Zasady przyzwoitej legislacji zostały sformułowane i ugruntowane w orzecznictwie TK. Stwierdził on, że wynikają one z art. 2 Konstytucji RP, bowiem stanowią element demokratycznego państwa prawnego i są przejawem zasad pewności i bezpieczeństwa prawnego oraz ogólnej zasady ochrony zaufania obywatela do państwa i stanowionego przez nie prawa $^{19}$. Trybunał definiuje pojęcie zasad (reguł) przyzwoitej legislacji, uznając je za „(...) dyrektywy określające sposób konstruowania aktów normatywnych, w tym wymagania dotyczące procesu legislacyjnego oraz wymagania dotyczące językowego ujęcia norm prawnych. W ramach tej zasady mieszczą się również dyrektywy wskazujące sposób dokonywania zmian w systemie prawa wpływających na zmianę sytuacji prawnej określonych podmiotów, dyrektywy wskazujące sposób ukształtowania rozstrzygnięć legislacyjnych, by nie miały one pozornego charakteru oraz dyrektywy określoności przepisów prawa”20.

Do zasad przyzwoitej legislacji TK zalicza m.in. zasadę określoności prawa, zgodnie z którą przepisy powinny być konstruowane w sposób:

- $\quad$ precyzyjny, tzn. gwarantujący ich jednolitą wykładnię i stosowanie,

- jasny, tzn. klarowny i zrozumiały dla adresatów oraz nie budzący wątpliwości co do treści nakładanych obowiązków i przyznawanych praw,

- $\quad$ poprawny pod względem językowym²1.

19 Zob. np. wyrok Trybunału Konstytucyjnego z dnia 25 kwietnia 2001 r., K. 13/01, OTK ZU 2001, nr 4, poz. 81; wyrok Trybunału Konstytucyjnego z dnia 19 kwietnia 2011 r., K 19/08, OTK ZU 2001, nr 3A, poz. 24; wyrok Trybunału Konstytucyjnego z dnia 24 lutego 2003 r., K 28/02, OTK ZU 2003, nr 2A, poz. 13; wyrok Trybunału Konstytucyjnego z dnia 16 grudnia 2009 r., Kp 5/08, OTK ZU 2009, nr 11A, poz. 170.

20 Wyrok Trybunału Konstytucyjnego z dnia 19 kwietnia 2011 r., K 19/08, OTK ZU 2001, nr 3A, poz. 24.

21 Wyrok Trybunału Konstytucyjnego z dnia 11 stycznia 2000 r., K 7/99, OTK ZU 2000, nr 1, poz. 2; wyrok Trybunału Konstytucyjnego z dnia 19 kwietnia 2011 r., K 19/08, 
Wśród reguł przyzwoitej legislacji wymienić można ponadto obowiązek ustanawiania odpowiedniej vacatio legis ${ }^{22}$ czy obowiązek formułowania celów w ramach procesu prawotwórczego, które mają zostać osiągnięte przez ustanowienie określonej normy prawnej ${ }^{23}$.

Wskazane zasady są istotne z punktu widzenia kontroli konstytucyjności aktów normatywnych. Stosownie bowiem do art. 42 ustawy o Trybunale Konstytucyjnym ${ }^{24}$, orzekając o zgodności aktu normatywnego z Konstytucją, Trybunał bada zarówno treść takiego aktu, jak też kompetencję oraz dochowanie trybu wymaganego przepisami prawa do wydania aktu.

Zasady przyzwoitej legislacji należy utożsamiać z zasadami techniki prawodawczej określonymi w rozporządzeniu prezesa Rady Ministrów $\mathrm{z}$ dnia 20 czerwca $2002 \mathrm{r}^{25}$

W świetle powyższych zasad tryb nowelizacji ustawy o finansach publicznych z dnia 26 lipca 2013 r. budzi szereg wątpliwości, zgłaszanych zresztą w trakcie prac legislacyjnych w sejmowej Komisji Finansów Publicznych. Pierwsza z nich została zasygnalizowana przez członka Biura Legislacyjnego Kancelarii Sejmu, który stwierdził, że projekt nowelizacji jest „obarczony dosyć istotną wadą legislacyjną”26. Miała ona polegać na tym, że wprowadzane przepisy zawieszające stosowanie I procedury ostrożnościowej i tymczasowej reguły wydatkowej mają charakter epizodyczny (incydentalny). W związku z tym nie powinny być umieszczone wśród przepisów materialnych ustawy o finansach publicznych, a powin-

OTK ZU 2001, nr 3A, poz. 24; wyrok Trybunału Konstytucyjnego z dnia 24 lutego 2003 r., K 28/02, OTK ZU 2003, nr 2A, poz. 13.

Wyrok Trybunału Konstytucyjnego z dnia 25 kwietnia 2001 r., K 13/01, OTK ZU 2001, nr 4, poz. 81.

23 Wyrok Trybunału Konstytucyjnego z dnia 16 grudnia 2009 r., Kp 5/08, OTK ZU 2009, nr 11A, poz. 170; wyrok Trybunału Konstytucyjnego z dnia 24 lutego 2003 r., K 28/02, OTK ZU 2003, nr 2A, poz. 13.

24 Ustawa z dnia 1 sierpnia 1997 r. o Trybunale Konstytucyjnym (Dz.U. Nr 102, poz. 642 ze zm.).

25 Rozporządzenie prezesa Rady Ministrów z dnia 20 czerwca 2002 r. w sprawie „Zasad techniki prawodawczej” (Dz.U. Nr 100, poz. 908), dalej: ZTP.

26 Biuro Komisji Sejmowych Kancelarii Sejmu, Zapis przebiegu posiedzenia Komisji Finansów Publicznych (nr 210) z dnia 24 lipca 2013 r., s. 30. 
ny znaleźć się w ustawie incydentalnej, albo w tzw. ustawie okołobudżetowej jako przepisy incydentalne, które mają zastosowanie tylko w roku 2013. Ponieważ nie posiadają one charakteru przepisów zmieniających, a tylko czasowo wyłączających stosowanie określonych regulacji ustawy o finansach publicznych. Zdaniem autora artykułu przepisy takie w świetle §47 ust. 1 ZTP, mogłyby się również znaleźć w ustawie - Przepisy wprowadzające ustawę o finansach publicznych ${ }^{27}$.

Kolejnym istotnym problemem dotyczącym procesu legislacyjnego analizowanego projektu jest brak jakichkolwiek opinii, których obowiązek przedstawiania przez odpowiednie organy wynika z odrębnych przepisów. Przykładem może tu być art. 21 pkt 3 ustawy o Narodowym Banku Polskim $^{28}$, zgodnie z którym NBP opiniuje projekty aktów normatywnych z zakresu polityki gospodarczej. Problem ten został podniesiony przez posłów podczas posiedzenia Komisji Finansów Publicznych po I czytaniu. W odpowiedzi na ten zarzut przewodniczący Komisji, Dariusz Rosati stwierdził, że to od Rady Ministrów zależy, czy dany projekt musi być opiniowany, czy też nie, „(...) ale z całą pewnością nie jest to warunek konieczny do tego, żeby procedować”29. Tymczasem powoływany art. 21 pkt 3 ustawy o Narodowy Banku Polskim nie pozostawia w tej kwestii żadnych wątpliwości. Nakłada on bezwzględny obowiązek opiniowania aktów z zakresu polityki gospodarczej, a projekt ustawy nowelizującej posiada taki charakter, chociażby $\mathrm{z}$ tego powodu, że daje podstawy do zwiększenia wydatków publicznych z budżetu państwa.

Wydaje się, że brak stosownych opinii był zdeterminowany potrzebą szybkiego uchwalenia projektu, która to wynikała jeszcze z innych powodów, o czym autor wspomni w dalszej części niniejszego artykułu. Sytuacja taka nie służy jednak realizacji zasad prawidłowej legislacji, a w szerszym znaczeniu stoi w pewnej opozycji do zasad pewności i bez-

27 Ustawa z dnia 27 sierpnia 2009 r. - Przepisy wprowadzające ustawę o finansach publicznych (Dz.U. Nr 157, poz. 1241 ze zm.).

28 Ustawa z dnia 29 sierpnia 1997 r. o Narodowym Banku Polskim (tekst jedn. Dz.U. z 2013 r., poz. 908 ze zm.).

29 Biuro Komisji Sejmowych Kancelarii Sejmu, Zapis przebiegu posiedzenia..., s. 36. 
pieczeństwa prawnego oraz zaufania obywatela do państwa i stanowionego przez nie prawa.

Wiele zastrzeżeń budzi treść uzasadnienia załączonego do projektu ustawy nowelizującej ${ }^{30}$. Spełnia ono istotną rolę zarówno w procesie legislacyjnym, jak i w późniejszym procesie dokonywania wykładni funkcjonalnej ustanawianych przepisów. W świetle zasad przyzwoitej legislacji projektodawca powinien jasno określić cele, jakie zamierza osiągnąć poprzez określoną inicjatywę prawodawczą, i czy można to zrobić, stosując odpowiednie środki prawne, tzn. stanowiąc normy prawne ${ }^{31}$. W tekście uzasadnienia omawianego projektu wskazuje się na kilka głównych argumentów uzasadniających potrzebę wprowadzenia zmian legislacyjnych.

Po pierwsze, projektodawca zauważa, że obowiązujące ograniczenia wzrostu wydatków budżetu państwa, które teraz miałyby ulec czasowemu zawieszeniu, spełniły swoją funkcję i pozwoliły Polsce na uniknięcie istotnego wzrostu długu publicznego. Mając jednak na uwadze procykliczność tych mechanizmów ograniczających wydatki publiczne, w tym wydatki prorozwojowe, ich zastosowanie w obecnej sytuacji gospodarczej utrudniałoby lub uniemożliwiłoby skuteczne przeciwdziałaniu dalszemu pogłębianiu spowolnienia gospodarczego ${ }^{32}$. Podkreśla się, że „(...) utrzymanie obecnych regulacji spowodowałoby w warunkach spowolnienia gospodarczego w Polsce, wynikającego z kryzysu w strefie euro, procykliczne spotęgowanie tego spowolnienia zamiast antycklicznego przeciwdziałania jemu."33

Po drugie, w związku z powyższym argumentem pozbawienie możliwości zwiększenia deficytu budżetu państwa wskutek wdrożenia I procedury ostrożnościowej, nie będzie służyło ani wyjściu z procedury nadmiernego deficytu (w której Polska się obecnie znajduje), ani nie przyczyni się do stabilizacji polskich finansów publicznych ${ }^{34}$.

30 Uzasadnienie do projektu ustawy o zmianie ustawy o finansach publicznych z dnia 16 lipca 2013 r. (druk sejmowy nr 1575).

31 Zob. szerzej S. Wronkowska, M. Zieliński, Komentarz do zasad techniki prawodawczej z dnia 20 czerwca 2002 r., Warszawa 2012, s. 52 i n.

32 Uzasadnienie do projektu ustawy o zmianie ustawy o finansach publicznych..., s. 2.

33 Tamże, s. 3.

34 Tamże, s. 2. 
Po trzecie, zawieszenie mechanizmu redukującego nadmierny wzrost deficytu budżetowego oraz tymczasowej reguły wydatkowej jest pierwszym etapem, który ma umożliwić podjęcie działań o charakterze antycyklicznym w postaci wprowadzenia jeszcze w roku 2013 nowej stabilizującej reguły wydatkowej ${ }^{35}$.

Tak skonstruowanemu uzasadnieniu projektu należy zarzucić brak przejrzystości, bowiem autorzy nie przedstawiają w klarowny sposób bezpośrednich powodów czasowego zawieszenia mechanizmów ograniczających wzrost wydatków budżetowych. Z jednej strony podkreśla się, że m.in. I procedura ostrożnościowa zapobiegła nadmiernemu przyrostowi długu publicznego, z drugiej zaś - w obecnym stanie polskiej gospodarki dalsze jej obowiązywanie, a przynajmniej obowiązywanie w 2013 r., nie służyłoby jej wyjściu z fazy spowolnienia. Tym samym koncepcja rządu sprowadza się do akceptacji wzrostu deficytu budżetowego i długu publicznego.

Rzeczywistym powodem omawianej nowelizacji ustawy o finansach publicznych były zbyt optymistyczne szacunki określonych kwot przyjętych w ustawie budżetowej na rok $2013^{36}$, m.in. odnoszących do wzrostu PKB i poziomu dochodów budżetowych. Ich przeszacowanie spowodowało potrzebę podniesienia kwoty deficytu budżetowego, do czego de facto przyznał się rząd, przygotowując projekt jej nowelizacji ${ }^{37}$. Właśnie w uzasadnieniu do tego projektu wskazuje on, że sytuacja ta jest wynikiem pogorszenia się koniunktury zewnętrznej wokół Polski, co w efekcie przełożyło się na spowolnienie wzrostu gospodarczego.

Przeprowadzona zmiana ustawy budżetowej na $2013 \mathrm{rr}^{38} \mathrm{w}$ globalnym rozrachunku sprowadziła się do zwiększenia różnicy między wydatkami i dochodami budżetu państwa, a więc zwiększenia poziomu nierów-

\footnotetext{
Tamże, s. 3.

Ustawa budżetowa na rok 2013 z dnia 25 stycznia 2013 r. (Dz.U. poz. 169).

Projekt ustawy o zmianie ustawy budżetowej na rok 2013 z dnia 21 sierpnia 2013 r. (druk sejmowy nr 1625).

38 Ustawa z dnia 27 września 2013 r. o zmianie ustawy budżetowej na rok 2013 (Dz.U. poz. 1212).
} 


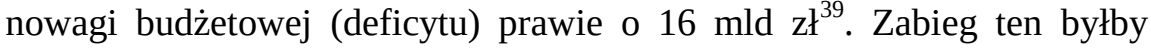
niemożliwy ze względu na obowiązywanie m.in. I procedury ostrożnościowej przewidzianej w art. 86 ust. 1 pkt 1 u.f.p. Tak więc nowelizacja ustawy o finansach publicznych z 26 lipca 2013 r. zawieszająca stosowanie tej procedury, umożliwiła zarówno odpowiednią zmianę ustawy budżetowej na rok 2013, jak i skonstruowanie projektu ustawy budżetowej na rok 2014 bez uwzględnienia tych ograniczeń, ale zgodnie nowymi zasadami, tj. w oparciu o nową stabilizującą regułę wydatkową. Co prawda rząd wspomniał o tym w uzasadnieniu do projektu zmian ustawy o finansach publicznych ${ }^{40}$, ale nie czynił tego w kontekście błędnego oszacowania dochodów budżetowych.

Podobnie bezkrytycznie oraz niekonsekwentnie podszedł projektodawca do ostatniego elementu uzasadnienia, tj. do oceny skutków regulacji. W części tej wskazuje, że projektowana nowelizacja będzie miała pozytywny wpływ na konkurencyjność gospodarki i przedsiębiorczość (w tym na funkcjonowanie przedsiębiorstw) oraz na sytuację i rozwój regionalny, jednocześnie nie uzasadniając takiego stanowiska. Jeżeli przyjąć, iż takie oddziaływanie wynikać będzie ze zwiększonych wydatków budżetowych, to dlaczego w punkcie „źródła finansowania” znajduje się informacja, że projektowana ustawa nie pociągnie za sobą wydatków z budżetu państwa lub budżetów jednostek samorządu terytorialnego? Co prawda bezpośredniego związku w tym zakresie dopatrzyć się nie można, ale skoro w pozytywnym świetle ocenia się wpływ projektowanych rozwiązań na daną dziedzinę życia wynikającą z wydatkowania środków publicznych, to dlaczego brak jest informacji o skutkach dla samych finansów publicznych w postaci zwiększonej nierównowagi w budżecie państwa, co w efekcie przełoży się na wzrost długu publicznego i kosztów jego obsługi?

39 Zgodnie z ustawą o zmianie ustawy budżetowej na rok 2013, dochody oszacowano na poziomie 275,7 mld zł, a więc o 23,7 mld zł mniej niż w pierwotnie przyjętym budżecie. Różnica ta ma zostać pokryta poprzez obniżenie kwoty wydatków o 7,7 mld zł, tj. do wysokości 327,3 mld zł, oraz podwyższenie deficytu o niecałe 16 mld zł, w efekcie czego wyniesie on 51,6 mld zł.

40 Uzasadnienie do projektu ustawy o zmianie ustawy o finansach publicznych..., s. 4-5. 


\section{Skutki zawieszenia stosowania I procedury ostrożnościowej}

Tak jak już autor nadmieniał, na mocy z art. 1 pkt 1 ustawy o zmianie ustawy o finansach publicznych ustawodawca postanowił o przejściowym - tj. do końca 2013 r. - zawieszeniu funkcjonowania I procedury ostrożnościowej. Jej wdrożenie przy zaistnieniu określonych przesłanek, ogranicza możliwość przekroczenia danego poziomu deficytu w projektowanej przez Radę Ministrów ustawie budżetowej. Pośrednio więc procedura ta stanowi również barierę dla wzrostu wartości państwowego długu publicznego. Zgodnie z treścią art. 86 ust. 1 pkt 1 u.f.p. w przypadku, gdy relacja kwoty państwowego długu publicznego do PKB przekroczy 50\%, a nie będzie większa niż 55\%, wówczas Rada Ministrów nie może uchwalić takiego projektu ustawy budżetowej na kolejny rok, w którym wartość relacji deficytu budżetu państwa do jego dochodów będzie wyższa niż wartość tej samej relacji, wynikającej z ustawy budżetowej obowiązującej w bieżącym roku budżetowym. W świetle aktualnej sytuacji budżetowej, należy podkreślić, że I procedura ostrożnościowa miała zastosowanie przy konstruowaniu projektu ustawy budżetowej na 2013 r. (oraz jej zmian w trakcie roku) oraz miałaby zastosowanie do projektu ustawy na rok kolejny, oczywiście gdyby nie analizowana nowelizacja. Zgodnie z obwieszczeniem ministra finansów stosunek długu publicznego do PKB za 2011 r. wyniósł 53,5 $\%{ }^{41}$, a za rok 2012 r. $-52,7 \%{ }^{42}$. Oznacza to, że w projektowanym na rok 2013 budżecie stosunek deficytu do dochodów budżetowych nie mógł przekroczyć poziomu $11,9 \%{ }^{43}$ i tyle w istocie wynióst. ${ }^{44}$

Reasumując, nowelizacja ustawy budżetowej na 2013 rok w zakresie podniesienia kwoty deficytu nie mogłaby zostać dokonana ze względu na

41 Obwieszczenie Ministra Finansów z dnia 22 maja 2012 r. w sprawie ogłoszenia kwot, o których mowa w art. 38 ustawy o finansach publicznych (M.P., poz. 355).

42 Obwieszczenie Ministra Finansów z dnia 21 maja 2013 r. w sprawie ogłoszenia kwot, o których mowa w art. 38 i art. 38a ustawy o finansach publicznych (M.P., poz. 459).

43 Zob. ustawa budżetowa na rok 2012 z dnia 2 marca 2012 r. (Dz.U., poz. 273).

44 Z kolei mając na uwadze zmodyfikowane kwoty dochodów i deficytu budżetu państwa w planowanej nowelizacji ustawy budżetowej na 2013 r. relacja ta wyniosła 18,7\%. 
mechanizm ograniczający określony w art. 86 ust. 1 pkt 1 u.f.p. Nie bez powodu rząd przyjął następującą sekwencję zdarzeń: najpierw zawieszenie stosowania powyższego przepisu poprzez odpowiednią nowelizację ustawy o finansach publicznych, a następnie zmiana ustawy budżetowej polegająca na obniżeniu kwoty planowanych dochodów budżetowych i podniesieniu deficytu budżetowego. I tą okolicznością należy tłumaczyć tak wielki pośpiech w pracach legislacyjnych nad zawieszeniem I procedury ostrożnościowej.

Pozostaje jeszcze podjąć kwestię, czy zawieszenie stosowania tej procedury w kontekście brzmienia art. 86 ust. 1 pkt 1 u.f.p. było rzeczywiście skuteczne w odniesieniu do zmian ustawy budżetowej na rok 2013. Z literalnego brzmienia powoływanego przepisu wynika, że w przypadku zaistnienia odpowiedniej relacji państwowego długu publicznego do PKB „[...] na kolejny rok Rada Ministrów uchwala projekt ustawy budżetowej, w którym relacja deficytu budżetu państwa do dochodów budżetu państwa nie może być wyższa [...]”, przy czym kluczowy tu jest sam zwrot „na kolejny rok”. Z jego kontekstu wynika, że ograniczenie wysokości deficytu, będące konsekwencją wdrożenia I procedury ostrożnościowej, ma zastosowanie tylko do projektu ustawy budżetowej przygotowanego na przyszły rok, ale już nie do projektów nowelizacji ustawy obowiązującej zgłaszanych w trakcie trwania danego roku budżetowego. W odniesieniu do analizowanej zmiany ustawy o finansach publicznych zawieszenie stosowania I procedury ostrożnościowej (a więc ograniczenie wzrostu deficytu budżetowego) będzie miało skutek tylko wobec projektu ustawy budżetowej na 2014 r., ale już w stosunku do projektu nowelizacji budżetu na rok 2013 procedura pozostanie obowiązująca. W konsekwencji wszelkie nowelizacje ustawy budżetowej w roku 2013 polegające na zwiększeniu deficytu budżetowego (łącznie z przeprowadzoną nowelizacją, o której autor już wspomniał) byłyby bezprawne, bowiem nastąpiłyby z pogwałceniem art. 86 ust. 1 pkt 1 u.f.p. Wykładnia literalna owego przepisu mogłaby prowadzić do powyższych konkluzji, jednakże należy dokonać szerszej analizy, nie tylko samego ust. 1 pkt 1, ale całego art. 86, uwzględniając cel, dla którego został on ustanowiony, oraz jego kontekst prawny. Przyjmując jednak na chwilę tak wąską wykładnię, jak przedsta- 
wiona powyżej (w zasadzie ograniczającą się tylko do wykładni literalnej), mogłoby się okazać, że Rada Ministrów w prosty sposób może omijać ograniczenia wzrostu deficytu wynikającego z tego przepisu. O ile musiałaby je uwzględniać w projekcie ustawy budżetowej na kolejny rok, o tyle już po wejściu w życie tego projektu w trakcie roku budżetowego mogłaby zaproponować jego nowelizację, która nie uwzględniałaby tego ograniczenia, bo jak wcześniej stwierdzono art. 86 ust. 1 pkt 1 u.f.p. nie ma zastosowania do takich projektów. Taka interpretacja wypaczałaby znaczenie art. 86 ust. 1 pkt 1 u.f.p. w ograniczaniu wzrostu wydatków z budżetu państwa, a po to został przecież ustanowiony, wobec czego należy stwierdzić, że zawieszenie stosowania tego przepisu na rok 2013 jest skuteczne wobec projektów nowelizacji ustawy budżetowej zarówno na ten rok, jak i na rok kolejny.

\section{Wnioski}

Chociaż analizowana w niniejszym artykule nowelizacja ustawy o finansach publicznych nie jest obszerna, to wywołuje ona istotne skutki prawne polegające m.in. na zawieszeniu stosowania I procedury ostrożnościowej. Pomimo kluczowego znaczenia tej zmiany przebieg procedury legislacyjnej budzi poważne zastrzeżenia, także o charakterze konstytucyjnym. Zastrzeżenia te odnoszą się do kwestii przestrzegania zasad przyzwoitej legislacji i dotyczą:

1. zbyt szybkiego trybu uchwalenia nowelizacji;

2. braku realizacji obowiązku opiniowania (konsultacji) projektu nowelizacji przez odpowiednie organy;

3. instrumentalnego potraktowania ustawy nowelizacyjnej; miała ona bowiem tylko i wyłącznie umożliwić późniejszą nowelizację ustawy budżetowej na rok 2013, która to została spowodowana optymistyczną prognozą strony dochodowej;

4. braku przejrzystości co do celów, które miałyby być osiągnięte w drodze nowelizacji; projektodawca nie wskazuje w uzasadnieniu do projektu jednoznacznie i bezpośrednio intencji, którymi się kierował, dokonując tych zmian; 
5. nieobiektywnej oceny skutków regulacji; zdaniem projektodawcy nowelizacja - a więc zawieszenie stosowania I procedury ostrożnościowej - będzie miała pozytywny wpływ zarówno na konkurencyjność gospodarki oraz przedsiębiorczość, jak i na rozwój regionalny. Nie wskazuje natomiast skutków nowelizacji dla samych finansów publicznych.

Wskazane mankamenty z pewnością nie służą spełnieniu zasad przyzwoitej legislacji, a w szerszym kontekście nie sprzyjają realizacji zasad pewności i bezpieczeństwa prawnego oraz zaufania obywatela do państwa i stanowionego przez nie prawa.

Z materialno-prawnego punku widzenia autor również negatywnie ocenia zawieszenie stosowania I procedury ostrożnościowej. Instytucja ta została wprowadzona do polskiego systemu prawnego (obok pozostałych procedur sanacyjnych) jako instrument ograniczający wzrost deficytu budżetowego. Była wyrazem dbałości o zdrowe finanse publiczne i jednocześnie realizowała konstytucyjne zasady stabilności finansowej, równowagi budżetowej i ograniczania długu publicznego. Jej faktyczna likwidacja (od 2014 r. zostaje w ogóle zniesiona) jest podyktowana bieżącą sytuacją budżetową oraz brakiem determinacji rządu w ograniczaniu wydatków publicznych. Realne przyczyny zawieszenia stosowania tej procedury w wyniku przeszacowania dochodów w budżecie na 2013 r. nie usprawiedliwiają ministra finansów i Rady Ministrów. Z art. 216 ust. 5 Konstytucji RP wynika bowiem ciążący na tych organach obowiązek stałego monitorowania zadłużenia publicznego (powodowanego w największym stopniu deficytem budżetowym) i podejmowania z wyprzedzeniem stosownych działań zapobiegawczych, a nie likwidowanie instrumentów temu zadaniu służących.

\section{Bibliografia:}

Dębowska-Romanowska T., Prawo finansowe. Część konstytucyjna wraz z częściq ogólnq, C.H. Beck, Warszawa 2010. 
Marcin Tyniewicki

Tyniewicki M., Procedury ostrożnościowe i sanacyjne, [w:] E. Ruśkowski, J.M. Salachna (red.), Finanse publiczne. Komentarz praktyczny, ODDK, Gdańsk 2013.

Wronkowska S., Zieliński M., Komentarz do zasad techniki prawodawczej z dnia 20 czerwca 2002 r., Wydawnictwo Sejmowe, Warszawa 2012. 